\title{
Likvärdighet och äldreomsorg - en introduktion
}

\author{
HÅKAN JÖNSON \& TITTI MATTSSON
}

Det här temanumret har tillkommit utifrån ett samarbete $i$ form av ett antal workshops med deltagare från två forskningsmiljöer vid Lunds universitet. Den ena miljön har namnet Omsorgens vardag och villkor och finns sedan ungefär 20 år vid Socialhögskolan i Lund. För närvarande finansieras flera forskare inom Omsorgens vardag och villkor av programstöd från Forskningsrådet för hälsa, arbetsliv och välfärd (FORTE, Dnr 2013:2296). Den andra miljön utgörs av Norma-programmet vid Juridiska fakulteten i Lund, även denna miljö med en 20-årig historia. Inom ramen för detta sistnämnda program finns sedan ett par år tillbaka en äldrerättsmiljö med ett tiotal forskare, möjliggjord genom generösa bidrag från Ragnar Söderbergs stiftelse samt Marianne and Marcus Wallenbergs stiftelse.

Under 2014 har de två miljöerna skapat ett samarbete i syfte att utveckla en mötesplats för tvärdisciplinär forskning. Två äldreforskare från Stockholms universitet med anknytning till det forskningsprogram som finansieras av FORTE har också medverkat.

Äldreforskning spänner över flera discipliner, varav socialt arbete och juridik är två centrala sådana. Redan inledningsvis fanns ambitionen att författa ett temanummer tillsammans och likvärdighetsbegreppet inom äldreomsorgen blev en gemensam nämnare som samtliga forskare fann fruktbar att analysera från olika perspektiv. Processen har innefattat totalt fyra seminarier, som löpt parallellt med en traditionell lektörsbedömningsprocess (och vi vill passa på att tacka de kollegor som anonymt bedömde manus till temanumret under sommaren 2014). I slutändan har sju originalartiklar kommit att ingå i temanumret: tre artiklar i socialt arbete, två artiklar i rättsvetenskap och två artiklar som använder en rättsvetenskaplig analys med socialvetenskapliga inslag. Därutöver har vi strävat efter att de recensioner och övriga artiklar som ingår också ska ha en anknytning till temat likvärdighet och äldreomsorg.

\section{Likvärdighet och äldreomsorg}

Begreppet likvärdighet har enligt ordboken betydelser som "motsvarande", "jämngod" och "jämlik". Mål om likvärdighet aktualiserar frågor om rättssäkerhet och behovet av rutiner och dokumenta- 
tion som säkerställer att människor inte behandlas på ett slumpmässigt eller orättvist sätt. Äldreomsorgen ska inte göra skillnad mellan äldre beroende av deras sociala bakgrund. Och det ska heller inte finnas omotiverade skillnader i behandlingen av äldre, jämfört med icke-äldre. Men likvärdighet får inte innebära att äldreomsorgen behandlar omsorgstagare enligt samma mall, utan med hänsyn till önskemål och behov.

Begreppet likvärdighet tycks hittills inte ha haft någon central betydelse inom äldreomsorgen, på det sätt som exempelvis gäller inom skolpolitik och funktionshinderpolitik. Samtidigt inbjuder begreppet till möjligheter att ställa viktiga frågor om äldreomsorg och andra hjälpverksamheter för äldre medborgare. Nedan ska vi ta skolpolitikens användning av likvärdighet som utgångspunkt för en sådan diskussion.

Enligt skollagen (SFS 2010:800) handlar likvärdighet både om att undvika skillnader i kvalitet mellan skolor i Sverige och att ge barn med särskilda behov samma skolgång som andra. Skolverket poängterar att utbildningen ska vara likvärdig och oberoende av sociala och ekonomiska hemförhållanden vilket också innebär att den ska kompensera för ogynnsamma hemförhållanden. I detta synliggörs två versioner av likvärdighet. Den ena handlar om att inte gynna medborgare elever i detta fall - som har en socioekonomiskt bättre position, vilket anknyter till principen om allas likhet inför lagen. Den andra versionen handlar om att kompensera för existerande ojämlikhet, och därmed uppnå likvärdighet. Denna version har bland annat varit synlig inom funktionshinderpolitiken, inte minst $\mathrm{i}$ relation till skolpolitiken och ambitionen att ge barn med funktionsnedsättningar en likvärdig skolgång oavsett funktionsnedsättningar (SOU 2007:87). Likvärdighet kan alltså både handla om att ha ett förhållningssätt där människor behan dlas lika i omedelbar bemärkelse och ett förhållningssätt där de behandlas olika för att uppnå en likvärdig situation. För äldreomsorgens del återfinns en skrivning om likvärdighet som förhållningssätt i kommunallagen (SFS 1991:900) där 2 kap. $2 \S$ anger att "[k]ommuner och landsting skall behandla sina medlemmar lika, om det inte finns sakliga skäl för något annat". En skrivning om likvärdighet som mål eller utfall återfinns i socialtjänstlagen (SFS 2001:453), där det i 1 kap. 1 § framgår att socialtjänsten ska "främja jämlikhet $i$ levnadsvillkor".

Ett känt talesätt inom äldreforskningen säger att vi föds som kopior och dör som original. Talesättet kan ses som ett försök att motverka stereotypa föreställningar om äldre som en likformig (grå) massa och tar fasta på det faktum att människor i hög ålder har olika livshistorier, erfarenhet, vanor, önskemål, behov utifrån hälsa och ohälsa etc. Dessutom innefattar kategorin "de äldre" människor från 65 till en bit över 100 år. I förarbetena till det kapitel i socialtjänstlagen som handlar om äldres rätt till ett värdigt liv betonar regeringen att äldreomsorgen ska bygga på valfrihet och att den som får omsorg ska kunna leva utifrån sin identitet och personlighet och "behålla sina intressen och vanor" (2009/10 SoU:18, s. 9). Det är också vanligt 
att beskrivningar av äldreomsorgen betonar vikten av att bevara omsorgstagarens identitet och motverka förändring som beror på omsorgenskontextens interna villkor - rutinerna (Harnett \& Jönson, 2010; Erlandsson, 2014).

Vi är alla lika inför döden, säger ett annat känt talesätt som på engelska uttrycks som att "death is the great leveler". Men ska också ålderdomen betraktas som en sådan "utjämnare"? Och äldreomsorgen? En likvärdighetsfråga handlar alltså om klass, ekonomi och socialpolitik. Ska den som haft en hög levnadsstandard under livet få hjälp av äldreomsorgen att "behålla sina intressen och vanor"? Det skulle kunna handla om att skapa äldreboenden med lite högre standard för personer som tidigare levt med lite högre standard. Ska den som tidigare har kunnat åka på semester till Mallorca med barnbarnen kunna fortsätta att göra det med hjälp av äldreomsorgens personal om den egna resan betalas privat? På en sådan resa skulle naturligtvis inte fattiga pensionärer kunna åka, vare sig de har behov av äldreomsorg eller inte. Ska äldreomsorgen bidra till att reproducera skillnader i levnadsstandard mellan äldre? Här ger socialtjänstlagen på sätt och vis motsägelsefulla budskap. Hjälpen ska ges en individuell utformning och ta hänsyn till önskemål och etablerade vanor, men hjälpen ska också syfta till att utjämna skilda levnadsvillkor. Ett sätt att hantera motsättningen är naturligtvis att minska äldreomsorgens uppdrag till att handla om en basnivå och sedan låta medborgarna själva välja vad de vill kosta på sig. Samtidigt innebär också detta att ojämlikhet i levnadsvillkor reproduceras och det finns en uppenbar risk för att medelklassens intresse av att försvara "basnivån" byts mot ett intresse av att förhandla om tilläggsnivåerna. Ett samhälle som överger målet om att tillhandahålla en äldreomsorg som är god nog för alla kommer troligen att ge de fattiga en sämre äldreomsorg. Frågan diskuteras av Marta Szebehely, i en utblicksartikel i detta temanummer.

En annan likvärdighetsfråga handlar om rätten till särart. Här har Owe Ronström (1996) fört en intressant diskussion utifrån begreppen social och kulturell tolkningsram. Svensk välfärdspolitik har präglats av en social tolkningsram, där likabehandling utgjort en garanti mot att vissa grupper och individer gynnas på grund av sin klasstillhörighet. Sedan ett par årtionden utmanas detta sätt att tänka om likhet som "alla behandlas lika" av en kulturell tolkningsram, där likabehandling blir en fråga om rätt till sin särart. En likvärdig äldreomsorg kan därmed handla om minoriteters rätt att erhålla äldreomsorg på sitt språk, eller i enlighet med sin kultur, dvs. att i ett vidare perspektiv behandlas på samma sätt som medlemmar av majoritetsbefolkningen (Heikkilä, 2010). Också här är det lätt att se konfliktområden. Inom vissa kulturer är det exempelvis vanligt att besked om allvarliga sjukdomar kommuniceras till de närstående, medan den som är äldre och har sjukdomen av hänsyn hålls ovetande. Ska det vara möjligt att göra så inom svensk äldreomsorg, med hänvisning till den kulturella särarten? 
Det likvärdiga existerar alltid i relation till någon eller något. I den diskussion vi fört ovan om klass och ekonomi, jämförs välbeställda och fattiga omsorgstagare med varandra och frågan handlar om reproduktion av ojämlika levnadsvillkor. I diskussionen om kulturell särart jämförs medlemmar av majoritets- och minoritetskulturer, enkelt uttryckt. Här finns det en viktig ingång för forskaren, som handlar om att undersöka de jämförelser till individer, grupper, villkor och situationer som åberopas (eller inte åberopas) i diskussioner om rättigheter. Inom skolpolitiken är det enkelt att identifiera relevanta jämförelser för likvärdighet - det handlar i allmänhet om andra skolor och andra elever, sannolikt andra elever i motsvarande ålder. En 12-åring ska få en skolgång som är likvärdig andra 12-åringars. Men vilka jämförelser är relevanta för äldre personer som behöver äldreomsorg? Ska likvärdigheten för äldre omsorgstagare relateras till de villkor som gäller för andra äldre omsorgstagare, eller till de villkor som gäller för äldre i allmänhet? Eller ska jämförelserna göras med yngre som har motsvarande hjälpbehov eller rent av till folk i allmänhet? Låt oss återvända till exemplet med pensionären som vill åka till Mallorca med hjälp av äldreomsorgens personal. För den som inte längre kan resa på grund av en funktionsnedsättning så skulle ju äldreomsorgen "främja jämlikhet i levnadsvillkor" genom att möjliggöra en sådan resa, om exempelvis äldre utan funktionsnedsättningar, eller folk i allmänhet används som jämförelsegrupp. Frågan är alltså vem jämlikheten och likvärdigheten ska relateras till.

\section{Temanumrets artiklar}

I det här temanumret behandlas frågor som på olika sätt anknyter till begreppet likvärdighet. Sex av artiklarna handlar om äldreomsorgen, den sjunde tar sin utgångspunkt i hälso- och sjukvården.

I artikeln Sill och potatis till den ena och entrecote till den andra? diskuterar Tove Harnett och Håkan Jönson individanpassning och likvärdighet på särskilda boenden för äldre. Studien bygger på intervjuer och observationer vid äldreboenden och identifierar en tendens inom äldreomsorgen att diskutera frågor om rättvisor och orättvisor utifrån "interna" jämförelser som hänvisar till omsorgskontexten, till andra omsorgstagare och till omsorgstagarens funktionsnedsättningar. I artikeln ställer Harnett och Jönson detta sätt att tänka i kontrast till de externa jämförelser som använts inom funktionshinderpolitiken, och som handlat om möjligheten att kunna leva som "andra".

Jämförelsen mellan äldre- och funktionshinderpolitik är också central i Sara Erlandssons artikel "Gammal" eller "funktionshindrad". Erlandsson tar avstamp i de anslående skillnader som finns mellan de insatser som ges till yngre respektive äldre personer med hjälpbehov och visar med hjälp av en diskursanalytisk ansats hur äldre och yngre hjälpmottagare konstrueras som två åtskilda kategorier. Att kategorierna framställs som ojämförbara innebär också att de skillnader i rättigheter som föreligger mellan äldre och yngre inte uppfattas som åldersdiskriminering enligt diskrimineringslagen. 
I artikeln Vardagens kontraktualisering, diskuterar David Hedlund individuella genomförandeplaner, vilket är en typ av dokument som blivit vanliga i äldreomsorgen. Planerna har införts med hänvisning till omsorgstagarens rättssäkerhet, men blir också ett sätt att skapa ett slags detaljerat kontrakt kring olika aspekter av vardagshjälpen. De kvantitativa och kvalitativa analyser Hedlund genomför visar att planerna är mycket olika i sin omfattning och karaktär, men olikheterna avspeglar skillnader i dokumenteringspraxis snarare än skillnader $i$ omsorgstagarnas behov.

I artikeln Valfrihet istället för jämlikhet - förändrade målsättningar för äldreomsorgspolitiken? diskuterar Mirjam Katzin utvecklingen av valfrihetssystem i äldreomsorgen som ett led mot en alltmer marknadsorienterad välfärd. Genom att använda teorier om det sociala medborgarskapet diskuterar författaren i vad mån denna utveckling kan komma i konflikt med socialtjänstlagens portalparagraf (1 kap. $1 \S)$, vilken anger att socialtjänsten ska främja jämlikhet i levnadsvillkor.

Många äldre har en begränsad beslutsförmåga, vilket gör att de kan behöva hjälp att fatta beslut och agera rättsligt. Det kan då aktualisera att en god man eller förvaltare behöver utses. Fråga uppstår då om vad ett sådant ställföreträdarskap omfattar och vad den äldre fortsatt kan få fatta beslut om. I artikeln Får jag inte bestämma något själv? En studie av kvarstående beslutanderätt hos dementa äldre redogör Eva Ryrstedt för vilken kvarstående beslutanderätt en äldre dement person har när en ställföreträdare som kan handla utan den enskildes samtycke är förordnad.

Nästa artikel rör ställer en annan fråga av betydelse för den äldres vardag och behandlar de äldres boende. Sedan början av 1990-talet har kommunerna fătt huvudansvaret för vård och omsorg för personer med omsorgsbehov, inklusive att tillhandahålla särskilda boendeformer (såsom servicelägenheter, vårdlägenheter och gruppboenden). I Hem eller vårdplats - hur behandlas personer med omsorgsbehov $i$ hyreslagstiftningen? utreder Per Norberg vad den äldres roll som hyresgäst i lägenheten, hemmet etc. innebär enligt hyreslagen samt relevanta hyresnämnders beslut och civilrättsliga domar.

Medan kommunerna har huvudansvaret för icke medicinsk långvarig service är det på landstingets ansvar att tillhandahålla läkarvård och sluten vård. Helene Brodin och Titti Mattsson utforskar hur hälso- och sjukvården bemöter äldre $\mathrm{i}$ artikeln Lägst ned på skalan? Hälso- och sjukvairdens bemötande av äldre kvinnor som migrerat till Sverige. Författarna beskriver hur det professionella bemötandet inom vården kan påverkas av omedvetna värderingar som gör att personer upplever sig kränkta eller särbehandlade. De diskuterar vidare skillnaden mellan lika och likvärdigt bemötande och vilken relevans det kan ha för professioner inom både vård och omsorg.

Temanumret avslutas med en utblicksartikel, där Marta Szebehely diskuterar möjligheterna att tillhandahålla en äldreomsorg som både är jämlik och individanpassad och en debattartikel där Adolf 
Ratzka argumenterar för möjligheten att även ge äldre personer, vars hjälpbehov uppstår efter 65-års ålder, rätt till personlig assistans.

Flera av de temanummer som Socialvetenskaplig tidskrift kommit ut med har rönt stor uppmärksamhet och använts inom utbildning, policydiskussioner och praktik. Vår förhoppning är naturligtvis att så också ska bli fallet med detta nummer.

\section{Referenser}

Erlandsson, S. (2014). Hjälp för att bevara eller förändra? Åldersrelaterade diskurser om omsorg, stöd och service. Akademisk avhandling. Stockholms universitet.

Harnett, T. och Jönson, H. (2010). That's not my Robert? Identity maintenance and other warrants in family members' claims about mistreatment in old-age care. Ageing \& Society, Vol. 30: 4,627-647.

Heikkilä, K. (2010). Kulturanpassad äldrevård. I S. Torres \& F. Magnússon (red.). Invandrarskap, äldrevård och omsorg. Malmö: Gleerups Utbildning AB.
Ronström, O. (1996). Äldre invandrare - från teori till praktik. I O. Ronström (red.). Vem ska ta hand om de gamla invandrarna. FoU-Rapport 1996:3. Socialtjänsten, Stockholm.

Socialutskottets betänkande 2009/10 SoU:18. Värdigt liv iäldreomsorgen.

SOU 2007:87. Ökad likvärdighet för elever med funktionshinder. Slutbetänkande av Utredningen om statliga specialskolor. 